J. Product. \& Dev., 24(4): 727-741(2019)

\title{
EFFECT OF MINERAL, ORGANIC AND BIO - FERTILIZERS ON GROWTH OF ZAGHLOUL DATE PALM
}

\section{Ashraf El-S. Aly and O. I. Zagzog}

Plant Production Department, Faculty of Technology and Development, Zagazig University, Egypt. zagzog_1000@yahoo.com

\section{ABSTRACT:}

This study was conducted to investigate the response of date palm (Phoenix dactylifera, L.) cv Zaghloul, to nine different fertilizer treatments i.e. Control $(1.5 \mathrm{~N})$, full nitrogen $(N)$ dose $(100 \%)$ as mineral fertilizer (recommended rate), quarter organic fertilizers $+3 / 4$ mineral, half- $N$ dose as organic fertilizers + half as mineral, full $N$ dose as organic fertilizer, quarter organic fertilizers $+3 / 4$ mineral + bio-fertilizers (EM). half- $N$ dose as organic fertilizers + half as mineral+ bio-fertilizers, full $N$ dose as organic fertilizer+ biofertilizers and bio-fertilizers. The experimental design was complete randomize block design with three replicates under El Adlia, Blbas, Sharkia Governorate, Egypt during two successive years (2017 and 2018).

The results showed that full $N$ dose as organic fertilizer+ biofertilizers gave the highest leaf number/palm, leaf length and leaf area index. Applied the full $N$ dose as organic fertilizer+ bio-fertilizers gave the highest number of leaflets/leaf and leaflet length whereas; addition bio-fertilizers only produced the highest value of leaflet width. Also, our results clear that added half $N$ dose as organic fertilizers + half as mineral enhanced the leaf chlorophyll content, but the addition full $N$ dose as organic fertilizer+ bio-fertilizers increased carotenoids content.

Conclusively, from previous results, it can concluded that organic and bio-fertilizers enhancement all vegetative growth parameters of Zaghloul date palm cv. To reduce dates pollution, prefer replacement mineral fertilizer by organic and bio-fertilizers.

Keywords: Date palm, fertilizer, organic, bio-fertilizer, vegetative growth 


\section{INTRODUCTION}

Zaghloul is one of the very important local date cvs. In most Egyptian regions. Date palm needs additional mineral nutrients but also the application of organic matter to enhance water retention. Date palm (Phoenix dactylifera L.) was an important crop in arid and semi-arid regions of the world. Date palm is one of the ancient domestic fruit trees in the Middle East countries and their fruits play an important role in the nutrition pattern of many people. It has always played an important turn in the economic and social life of the people of these regions. Owing to date palm can grow and produce under a wide range of soil and climatic conditions, growers have mistakenly believed that it does not require much attention.

The successful orchard management practices directed toward obtaining a suitable yield with good fruit quality. Date fruits are very popular in the Arab and Islamic counties. Zaghloul is one of the very important local date cvs. In most Egyptian regions. It has well known that the nutrient requirements of the date palms could fulfilled through the fertilizers application for inter planted crops. However, this pattern of application depends on soil texture and the interplant crops. Aseri et al. (2008) found that the use of bio-fertilizers significantly improved yield and fruit quality of pomegranate in India. In addition, Bio-fertilization considered a positive alternative to chemical fertilization lost the enhancing enhance citrus yield and fruit quality, because it is safe for human, animal, and environment. Using bio-fertilizers in organic food production accompanied with the reduction of environmental pollution.

Date palm needs additional mineral nutrients but also the application of organic matter to enhance water retention. Organic amendments not only improve soil conditions but also can be an important source for plant nutrients and slow the availability of mobile nutrients (Bhangoo et al., 1988; Hegazi et al., 2007). Bio fertilizers are biological preparations containing primary potent strains of microorganisms in sufficient numbers to increase the plant dry weight, leaf chlorophyll and net assimilation rate (El- Gamal, 1996). These microorganisms have a definite beneficial role in the fertility of rhizosphere soil. Application of mineral fertilizers with organic or biofertilizers proved to be highly effective in improving nutritional status, fruiting and fruit quality of various fruit trees (Abd El-Migeed et al., 2006; Hegazi et al., 2007). 
EM contains selected species of microorganisms including three principal types of organisms namely lactic acid bacteria, yeast actinomyces and photosynthetic bacteria that commonly found in soils (Higa, 1991). EM used to improve soil fertility and plant growing conditions (Higa, 1991 and Higa and Wididana, 1991). Rokba et al. (1975) found that tree growth was better and canopy volume improved in trees received organic fertilization, and this effect more pronounced at the higher fertilization rate. In deciduous trees, they have a positive effect on the vegetative growth of Navel orange trees. The organic fertilization increases soil water retention during drought, and drainage in wet condition (Eghaball and Power, 1994). Nakhlla et al. (1998) stated that $\mathrm{N}$ fertilization increased trunk diameter of 'Washington' Navel orange. El Kobbia, (1999) studied the response of 'Washington' Navel orange to 'bio-humus' organic fertilizer and cattle manure. He noticed that 'bio-humus' significantly increased vegetative growth in comparison to cattle manure. Ebrahiem and Mohamed (2000) found that the application of Farmyard manure (FYM) and Filter mud (FM) in combination with the mineral $\mathrm{N}$ improved shoot length of 'Balady' mandarin trees. Gamal and Ragab (2003), found that combined application of inorganic and organic fertilizers increased leaf area compared to either inorganic or organic fertilizers supplied alone to Balady mandarins. Abd-Rabouo, (2006) found that bio ferrilizarion of Mango and Avocado seedlings with Microben increased leaf area, and this effect increased as the rate of application increased. Other reports indicated that poultry manure treatment increased number of shoots per plant, number of leaves per shoot, and leaf area $\left(\mathrm{cm}^{2}\right)$ of olive trees, compared with mineral and bio- fertilization (Hegazi et al., 2007). Wassel et al. (2007) reported an increase in spring shoot length and leaf area of 'Balady' mandarin achieved with increased $\mathrm{N}$ levels and rate of application. The effect of different organic and bio- fertilizers on 'Washington' Navel orange growth and development studied, and results revealed that poultry manure produced the highest shoot length and leaf area, followed by rabbit manure, but cattle manure was the least effective. Results also showed that bio- fertilization with Rhizobacterien enhanced shoot length compared with Nitrobien.

Vegetative growth and productivity of 'Amrapali' mango improved with a combination of NPK (100\% or $75 \%)$ and biofertilizers (Azotobacter and vesicular arbuscular mycorrhiza) (Kundu et al., 2011). 
Nitrogen fertilization combined with inoculation with Bacillus polymyxa increased leaf mineral content and improved growth rate of 'Zebda' mango trees grown in clay loamy soil (Rabeh et al., 2012). Ortas and Ustuner (2014) metion that Mycorrhizal inoculation increased certain plant growth parameters such as shoot height, diameter, and shoot and root dry matter of sour orange (Citrus aurantium L.) seedlings, using EM1 was materially superior to using yeast in enhancing all growth traits and enhancing all leaf pigments of Williams banana plants. Abd El- Rahman and Mansour (2015).

Supplying 'Sukkary' mango 50\% mineral N $+50 \%$ chicken manure +50 $\mathrm{ml}$ EM per tree showed the maximum values of shoot length and thickness, number of leaves per shoot, and leaf dimensions. This effect continued for three growth cycles (Ahmed et al., 2015). Ennab (2016) recoded that treatment of $50 \% \mathrm{NPK}+55 \mathrm{~kg}$ farmyard manure + biofertilizers for Eureka lemon trees gave the best growth. Mohamed and Massoud (2017) proved that biofertilizer combined with mineral fertilizer had more positive effects than both microbial inoculants solely and non-inoculated control. Azotobacter + AM at $75 \%$ or $50 \%$ induced significant increment in growth criteria (leaf fresh and dry weights and tree height or volume) on orange trees Osbeck) $c v$. Washington navel orange. Abd-Ella et al. (2010) showed that, vegetative growth improved under all treatments different fertilizers minerals at rate of $100 \%$ or $50 \%$ of recommended dose or organic (humic acid or compost solely) of Arabipomegranate trees. Amro et al. (2014) showed that preferable to add EM at 90 $\mathrm{ml} / \mathrm{palm} /$ year combined with potassium sulphate at $1.5 \mathrm{~kg} / \mathrm{palm} /$ year as a soil application divided into three equal doses applied at three times a year to enhance leaf chlorophyll content of "Hayany" date palm. Poultry manure was the most effective organic fertilizer to increase the chlorophyll a and $b$ content of orange trees. This effect more pronounced when poultry manure combined with a biofertilizer 'rhizobacterien' rather than 'Nitrobeine' (Helail et al., 2003). Mohamed and Massoud (2017) proved that biofertilizer combined with mineral fertilizer had more positive effects than both microbial inoculants solely and non-inoculated control. Azotobacter $+\mathrm{AM}$ at $75 \%$ or $50 \%$ induced significant increment in chlorophyll content of orange trees cv. Washington navel orange.

Therefore, the present research work aimed to provide the bestcombined application of mineral, organic, and bio- fertilization that could use 
to gradually replace regular mineral fertilization programs and the improve growth parameters of Zaghloul date palm cultivar.

\section{MATERIALS AND METHODS:}

This investigation carried out on the Zaghloul date palm cultivar in 2017 and 2018 seasons grown in line sandy soil under drip irrigation, at a private orchard in El Adlia Blbas, Sharkia Governorate, Egypt.

Seven twenty palms, as uniform as possible, randomly selected for the study, planted at $10 \times 10$ meters apart for this experiment. The experimental design in a randomized complete block design (RCBD) experiment divide to nine treatments with three replicates (one palm/replicate) for each treatment. The tested treatments will be as follows:

1. Control. $(0.0 \mathrm{~N})$.

2. Full N dose (100\%) (NH4-SO3) as mineral fertilizer (recommended rate).

3. Quarter organic fertilizers $+3 / 4$ mineral.

4. Half-N dose as organic fertilizers + half as mineral.

5. Full $\mathrm{N}$ dose as organic fertilizer.

6. Quarter organic fertilizers + 3/4 mineral + bio-fertilizers (EM).

7. Half-N dose as organic fertilizers + half as mineral+ bio-fertilizers (EM).

8. Full $\mathrm{N}$ dose as organic fertilizer+ bio-fertilizers (EM).

9. Bio-fertilizers (EM).

Soil application of EM bio-fertilizer and nitrogen fertilizers are divided into three doses apply on February $1^{\text {st }}$ (before flowering), May, $1^{\text {st }}$ (Cell division) and July, $1^{\text {st }}$ (Cell elongation) in each season. The experimental palms immediately irrigated after treatments.

All spathes on each palm sprayed once with boric acid, 2-3 days after spathe cracking (before pollination) during April in the two experimental seasons. The same pollen source used to pollinate the experimental palms during the two seasons of study.

\section{Vegetative growth characteristics}

In order to determine vegetative growth and its mineral content, twenty pinnae per each replicate collected in November, from the middle pinnae of the full-developed leaves around the axis above fruiting zone as recommended by Abdalla et al., (1998). For each pinnae sample, length and 
maximum width were determined. Pinnae (leaflet) area calculated according to the equation of Shabana and Antoun (1980) as follows:

Leaflet area $=$ Length $\times$ Maximum width $\times 0.84$.

Length of new growing leaves were determined at the end of each growth season, average number of pinnae/leaf was determined for mature leaves, and leaf area was calculated by multiplying the average pinnae area by average number of pinnae/leaf. Leaf pigments contents: Leaf disk samples obtained at harvest to determined leaf tissue contents (mg/mg F.W) of chlorophyll A\&B, total chlorophyll and carotenoids (Wettestein, 1957).

\section{Statistical analysis}

This investigation carried out on the Zaghloul date palm cultivar in 2017 and 2018 seasons grown in line sandy soil under drip irrigation, at a private orchard in El Adlia Blbas, Sharkia Governorate, Egypt.

Data will be subject to the analysis of variance and the Complete Random Design will be used (Steel and Torrie, 1980). The significant differences between treatment means were separated using Duncan's multiple range test (1955).

\section{RESULTS AND DISCUSSIONS:}

\section{Leaf characters:}

The results presented in Table 1 show the number of leaves/palm, leaf length and leaf area of leaves have significant effect by different fertilizers components during 2017 and 2018 seasons.

Data listed in same table reveal that the different fertilizers significantly affected number of leaves/palm. Addition that full nitrogen dose as organic fertilizer + bio-fertilizers (EM) gave the highest values of number of leaves/palm during the two seasons (26.3 and 28.0 leaves, respectively). Full $\mathrm{N}$ dose as organic fertilizer came in the second rank in the second season (28.3 leaves). Control treatment was produced the lowest number of leaves/palm during two seasons. From this data, it appears that the control treatment gave the lowest value of leaf length $(3.53$ and $3.51 \mathrm{~m})$ compared to other fertilizer treatments. The highest leaf length obtained when added full nitrogen dose as organic fertilizer+ bio-fertilizers through 2017 and 2018 seasons (4.40 and $4.34 \mathrm{~m}$, respectively). Regarding to leaf 
Table (1): Impact of mineral, organic and bio-fertilizers on leaf characters of Zaghloul date palm during 2017 and 2018 seasons.

\begin{tabular}{|l|l|l|l|l|l|l|}
\hline \multicolumn{1}{|c|}{ Characters } & \multicolumn{2}{c|}{$\begin{array}{c}\text { Number of } \\
\text { leaves/palm }\end{array}$} & \multicolumn{2}{c|}{$\begin{array}{c}\text { Leaf length } \\
\text { (m) }\end{array}$} & \multicolumn{2}{c|}{$\begin{array}{c}\text { Leaf area } \\
\text { index (m }\end{array}$} \\
\hline Treatments & $\mathbf{2 0 1 7}$ & $\mathbf{2 0 1 8}$ & $\mathbf{2 0 1 7}$ & $\mathbf{2 0 1 8}$ & $\mathbf{2 0 1 7}$ & $\mathbf{2 0 1 8}$ \\
\hline Control & 24.0 & 23.3 & 3.53 & 3.51 & 2.59 & 3.45 \\
\hline $\begin{array}{l}\text { Full N dose (100\%) as } \\
\text { mineral fertilizer }\end{array}$ & 26.0 & 26.7 & 4.32 & 4.25 & 3.20 & 4.79 \\
\hline $\begin{array}{l}\text { Quarter organic fertilizers + } \\
\text { 3/4 mineral }\end{array}$ & 25.7 & 26.7 & 4.28 & 4.28 & 3.28 & 4.58 \\
\hline $\begin{array}{l}\text { Half N dose as organic } \\
\text { fertilizers + half as mineral }\end{array}$ & 24.3 & 26.7 & 3.95 & 4.24 & 3.21 & 4.74 \\
\hline $\begin{array}{l}\text { Full N dose as organic } \\
\text { fertilizer }\end{array}$ & 25.7 & 28.3 & 4.23 & 4.25 & 3.32 & 4.91 \\
\hline $\begin{array}{l}\text { Quarter organic fertilizers + } \\
\text { 3/4 mineral + bio-fertilizers } \\
\text { (EM) }\end{array}$ & 24.3 & 27.7 & 3.94 & 4.23 & 4.16 & 4.80 \\
\hline $\begin{array}{l}\text { Half N dose as organic } \\
\text { fertilizers + half as mineral+ } \\
\text { bio-fertilizers EM) }\end{array}$ & 24.7 & 27.3 & 4.09 & 4.25 & 3.69 & 4.90 \\
\hline $\begin{array}{l}\text { Full N dose as organi } \\
\text { fertilizer+ bio-fertilizers(EM) }\end{array}$ & 26.3 & 28.4 & 4.40 & 4.34 & 5.02 & 4.94 \\
\hline Bio-fertilizers (EM) & 24.3 & 24.0 & 3.97 & 4.23 & 4.90 & 4.84 \\
\hline LSD at 5\% & $\mathbf{1 . 5}$ & $\mathbf{1 . 2}$ & $\mathbf{0 . 0 9}$ & $\mathbf{0 . 0 3}$ & $\mathbf{0 . 1 9}$ & $\mathbf{0 . 1 8}$ \\
\hline
\end{tabular}

area index the data shows that there is a significant effect between different fertilizer treatments. In addition, it appears that the control gave the lowest value of leaf area index compared to other treatments.

The values of full nitrogen dose as organic fertilizer+ bio-fertilizers were the highest compared with the other fertilizer components during two seasons (5.02 and 4.94, respectively).

The enhancement of number of leaves/palm, leaf length and leaf area index it may be due to activation of microorganisms and soil condition to keep water available and other nutrients. These results are consistent with the results of El Kobbia, (1999) and Wassel et al. (2007) on Navel orange, Ebrahiem and 
Mohamed (2000) on 'Balady' mandarin trees, Ahmed et al. (2015), Ennab (2016) and Mohamed and Massoud (2017).

\section{Leaflets characters:}

Data presented in Table (2) shows that the mineral, organic and biofertilizers have significant effect on the leaflets characters of Zaghloul date palm during 2017 and 2018 seasons. Regarding the effect of fertilizer treatments on the number of leaflets/leaf, data in Table 2 revealed that it had a non-significant effect in the 1 st season whereas it was significant effect in the $2^{\text {nd }}$ one. The control treatment always keeps the lowest values (220.3 and 223.7 leaflets/leaf, respectively). Full nitrogen dose as organic fertilizer+ bio-fertilizers (EM) recorded the highest values in the two seasons (225.0 and 228.7 leaflets/leaf, respectively) compared with the other treatments. The data in Table (2), revealed that mineral, organic and bio-fertilizer treatments have significant effect on leaflet length. Full nitrogen dose as organic fertilizer+ bio-fertilizer increasing leaflet length $(\mathrm{cm})$ without significant differences with treatments of half $\mathrm{N}$ dose as organic fertilizers + half as mineral+ bio-fertilizers and bio-fertilizers. The data in the same table shows that the fertilizer treatments have significant increase of leaflet width $(\mathrm{cm})$. It appears that the control treatment gave the lower value of leaflet width compared to other treatments.

On the other hand, bio-fertilizers treatment recorded the highest leaflet width during two seasons (4.12 and $4.16 \mathrm{~cm}$, respectively) without significant differences with organic fertilizer+ bio-fertilizer. These results were in harmony with those obtained by Rabeh et al. (2012), Ortas and Ustuner (2014), who stated the Mycorrhizal inoculation, increased certain plant growth parameters, Abd El-Rahman and Mansour (2015) on Williams's banana plants.

\section{Leaf pigments content:}

Data collected on leaf pigments content as affected by different fertilizer treatments listed in Table 3. The data revealed that control treatment was recorded the lowest values for leaf pigments content Half $\mathrm{N}$ dose as organic fertilizers + half as mineral gave the highest values of chlorophyll A (1.95 and 1.99 $\mathrm{mg} / \mathrm{F} . \mathrm{W}$ ), chlorophyll B (2.94 and $2.97 \mathrm{mg} / \mathrm{F} . W$ ) and total chlorophyll (4.85 and $4.96 \mathrm{mg} / \mathrm{F}$.W) during 2017 and 2018 seasons, respectively. According to carotenoids pigment in pinnae Zaghloul, the data shows that there is a significant effect between fertilizer treatments. Application full $\mathrm{N}$ dose as organic fertilizer+ bio-fertilizers to palms recorded the highest value of carotenoids during two seasons (3.27 and 3.22 $\mathrm{mg} / \mathrm{F} . \mathrm{W}$, respectively) as compared the other treatments. 
Table (2): Impact of mineral, organic and bio-fertilizers on leaflets characters of Zaghloul date palm during 2017 and 2018 seasons.

\begin{tabular}{|l|l|l|l|l|l|l|}
\hline Characters & \multicolumn{3}{|l|}{$\begin{array}{l}\text { Number of } \\
\text { leaflets/leaf }\end{array}$} & \multicolumn{2}{l|}{$\begin{array}{l}\text { Leaflet length } \\
\text { (cm) }\end{array}$} & \multicolumn{2}{l|}{$\begin{array}{l}\text { Leaflet width } \\
\text { (cm) }\end{array}$} \\
\hline Treatments & $\mathbf{2 0 1 7}$ & $\mathbf{2 0 1 8}$ & $\mathbf{2 0 1 7}$ & $\mathbf{2 0 1 8}$ & $\mathbf{2 0 1 7}$ & $\mathbf{2 0 1 8}$ \\
\hline Control & 220.3 & 223.7 & 46.3 & 48.3 & 3.02 & 3.80 \\
\hline $\begin{array}{l}\text { Full N dose (100\%) as } \\
\text { mineral fertilizer }\end{array}$ & 224.3 & 226.0 & 55.0 & 61.3 & 3.08 & 4.12 \\
\hline $\begin{array}{l}\text { Quarter organic } \\
\text { fertilizers + 3/4 mineral }\end{array}$ & 223.3 & 224.7 & 56.0 & 59.0 & 3.12 & 4.11 \\
\hline $\begin{array}{l}\text { Half N dose as organic } \\
\text { fertilizers + half as } \\
\text { mineral }\end{array}$ & 222.0 & 224.3 & 54.7 & 61.0 & 3.15 & 4.12 \\
\hline $\begin{array}{l}\text { Full N dose as organic } \\
\text { fertilizer }\end{array}$ & 223.0 & 226.0 & 55.7 & 62.0 & 3.16 & 4.13 \\
\hline $\begin{array}{l}\text { Quarter organic } \\
\text { fertilizers + 3/4 mineral } \\
+ \text { bio-fertilizers (EM) }\end{array}$ & 222.7 & 226.3 & 55.7 & 61.3 & 4.00 & 4.12 \\
\hline $\begin{array}{l}\text { Half N dose as organic } \\
\text { fertilizers + half as } \\
\text { mineral+ bio-fertilizers } \\
\text { (EM) }\end{array}$ & 221.3 & 227.7 & 62.3 & 62.0 & 3.18 & 4.14 \\
\hline $\begin{array}{l}\text { Full N dose as organic } \\
\text { fertilizer+ bio-fertilizers } \\
\text { (EM) }\end{array}$ & 225.0 & 228.7 & 65.7 & 62.7 & 4.08 & 4.15 \\
\hline Bio-fertilizers (EM) & 223.7 & 228.3 & 63.3 & 60.7 & 4.12 & 5.16 \\
\hline LSD at 5\% NS & 1.2 & 2.6 & 1.9 & 0.01 & 0.09 \\
\hline
\end{tabular}

The present results obtained by Amro et al. (2014), who mentioned that add $\mathrm{EM}$ at $90 \mathrm{ml} / \mathrm{palm} /$ year combined with potassium sulphate at 1.5 $\mathrm{kg} / \mathrm{palm} /$ year enhancement of leaf chlorophyll content of "Hayany" date palm. In addition, Helail et al. (2003) organic fertilizer caused increasing the chlorophyll a and b content of orange trees. Moreover, results of El- Gamal, 1996; Mohamed and Massoud (2017), Abd El- Rahman and Mansour (2015) came in the same line with our results on orange trees. 
Table (3): Impact of mineral, organic and bio-fertilizers on leaf pigments content of Zaghloul date palm during 2017 and 2018 seasons.

\begin{tabular}{|l|l|l|l|l|l|l|l|l|}
\hline \multicolumn{1}{|c|}{ Characters } & \multicolumn{2}{|c|}{$\begin{array}{c}\text { Chlorophyll A } \\
\text { (mg/F.W) }\end{array}$} & \multicolumn{2}{c|}{$\begin{array}{c}\text { Chlorophyll B } \\
\text { (mg/F.W) }\end{array}$} & \multicolumn{2}{c|}{$\begin{array}{c}\text { Total } \\
\text { chlorophyll } \\
\text { (mg/F.W) }\end{array}$} & \multicolumn{2}{c|}{$\begin{array}{c}\text { Carotenoids } \\
\text { (mg/F.W) }\end{array}$} \\
\hline Treatments & $\mathbf{2 0 1 7}$ & $\mathbf{2 0 1 8}$ & $\mathbf{2 0 1 7}$ & $\mathbf{2 0 1 8}$ & $\mathbf{2 0 1 7}$ & $\mathbf{2 0 1 8}$ & $\mathbf{2 0 1 7}$ & $\mathbf{2 0 1 8}$ \\
\hline Control & 1.32 & 1.42 & 2.24 & 2.30 & 3.56 & 3.73 & 2.36 & 2.67 \\
\hline $\begin{array}{l}\text { Full N dose (100\%) as } \\
\text { mineral fertilizer }\end{array}$ & 1.86 & 1.76 & 2.90 & 2.31 & 4.76 & 4.06 & 2.78 & 3.20 \\
\hline $\begin{array}{l}\text { Quarter organic } \\
\text { fertilizers + 3/4 mineral }\end{array}$ & 1.83 & 1.86 & 2.76 & 2.81 & 4.59 & 4.67 & 3.02 & 2.98 \\
\hline $\begin{array}{l}\text { Half N dose arganic } \\
\text { fertilizers + half as } \\
\text { mineral }\end{array}$ & 1.95 & 1.99 & 2.94 & 2.97 & 4.85 & 4.96 & 2.98 & 2.87 \\
\hline $\begin{array}{l}\text { Full N dose as organic } \\
\text { fertilizer }\end{array}$ & 1.74 & 1.82 & 2.68 & 2.72 & 4.42 & 4.54 & 3.13 & 3.03 \\
\hline $\begin{array}{l}\text { Quarter organic } \\
\text { fertilizers + 3/4 mineral } \\
+ \text { bio-fertilizers (EM) }\end{array}$ & 1.58 & 1.62 & 2.55 & 2.61 & 4.14 & 4.23 & 2.85 & 2.92 \\
\hline $\begin{array}{l}\text { Half N dose as organic } \\
\text { fertilizers + half as } \\
\text { mineral+ bio-fertilizers } \\
\text { (EM) }\end{array}$ & 1.47 & 1.51 & 2.69 & 2.94 & 4.17 & 4.44 & 3.26 & 3.11 \\
\hline $\begin{array}{l}\text { Full N dose as organic } \\
\text { fertilizer+ } \\
\text { fertilizers (EM) }\end{array}$ & 1.91 & 1.92 & 2.85 & 2.81 & 4.76 & 4.73 & 3.27 & 3.22 \\
\hline Bio-fertilizers (EM) & 1.82 & 1.83 & 2.76 & 2.78 & 4.58 & 4.62 & 3.20 & 3.18 \\
\hline LSD at 5\% & $\mathbf{0 . 0 2}$ & $\mathbf{0 . 0 0 8}$ & $\mathbf{0 . 0 0 5}$ & $\mathbf{0 . 0 0 9}$ & $\mathbf{0 . 0 2 4}$ & $\mathbf{0 . 0 1 4}$ & $\mathbf{0 . 0 0 5}$ & $\mathbf{0 . 0 1}$ \\
\hline
\end{tabular}

Conclusively, from previous results, it can concluded that organic and bio-fertilizers enhancement all vegetative growth parameters of Zaghloul date palm cv. To reduce dates pollution prefer replacement mineral fertilizer by organic and bio-fertilizers. 


\section{REFERENCES}

Abdallah A., Ahumada M.H., Gradziel T.M., (1998). Oil content and fatty acid composition of almond kernels from different genotypes and California production regions. J. Am. Soc. Hort. Sci., 123, 1029-1033.

Abd-Ella, Eman EK, S. S. Mervate, and A. Z. Wafaa. (2010). "Effect of some organic and mineral fertilizer applications on growth and productivity of pomegranate trees." Alex. Sci. Exchange J., 31.3: 296-304.

Abd El-Migeed, M.M., El-Ashry, S. \& Gomaa, A.M. (2006). The Integrated Fertilization of Thompson Seedless Grapevines with Organic Manures, Bio-fertilizers and Low Dose of Mineral Nitrogen. Res. J. Agric \& Biol Sci, 2, 460-466.

Abd-Rabou, S. (2006) "Hymenopterous parasitoids as a bioagent for controlling homopterous insects in Egypt." J. of Agric. Rese. 6: 159.

Abd El- Rahman, M. M. A. (2015). Relation of spraying silicon with fruiting of Keitt mango trees growing under Upper Egypt conditions. Stem Cell: 6 (2):1-5.

Abd El- Rahman, M. M. A. and Mansour, A. E. M. (2015). Response of Williams Banana Plants to Application of EM1 and Yeast extract. Middle East J. Agric., 4 (2): 277-282.

Amro S.M. Salama, Omima M. El- Sayed, Osama H.M. El Gammal. (2014). Effect of Effective Microorganisms (EM) and Potassium Sulphate on Productivity and Fruit Quality of "Hayany" Date Palm Grown Under Salinity Stress. IOSR J. of Agri. and Veterinary Sci., 7:90-99.

Aseri, G. K., Jain, N., Panwar, J., Rao, A. V., \& Meghwal, P. R. (2008). Biofertilizers improve plant growth, fruit yield, nutrition, metabolism and rhizosphere enzyme activities of pomegranate (Punica granatum L.) in Indian. Thar Desert. Scientia hort. 130-13.

Bhangoo, M.S.; K.S. Day; V.R. Sudanagunta and V.E. Petrucci (1988). Application of poultry manure influences Thompson seedless grape production and soil properties. Hort. Sci., 23 (6): 1010-1012. 
Chamberlain, T.P.; Daly, M.J. and Merfield, C.N., (1997). Utilization of Effective Microorganisms in Commercial Organic Agriculture: A Case Study from New Zealand. Proc. 5th International Kyusei Nature Farming Conference, Bangkok, Thailand, 120-123.

Diab, M. S., Massoud, A. M., Ahmed, S., \& Williams, B. W. (2017). A dual modular multilevel converter with high-frequency magnetic links between submodules for MV open-end stator winding machine drives. IEEE Transactions on Power Electronics, 33(6), 5142-5159.

Duncan, D.B. (1955). Multiple range and Multiple F test. Biometrics, 11:1- 42 .

Ebrahiem, T. A., and G. A. Mohamed. (2000). "Response of Balady mandarin trees growing on sandy soil to application of filter mud and farmyard manure." Assiut J. of Agri. Sci., 31(5): 55-69.

Eghaball B, Power JE (1994). Beef cattle feedlot manure management. $J$. Soil Water Conserv, 49: 113 - 122

El-Gamal, A.M. (1996). Response of tomato in new reclaimed areas to mineral nitrogen fertilizer levels and nitrogen fixing biofertilizer. Assuit J. Agric. Sci, 27: 89-99.

El-Kobbia, A. M. (1999). Response of Washington navel orange to organic fertilizer "biohumus" and cattle manure application. Alex. J. Agric. Res., 44(2): 199-207.

Ennab, Hassan A. (2016). "Effect of humic acid on growth and productivity of egyptian lime trees (citrus aurantifolia swingle) under salt stress conditions." J. Agric. Res. Kafr El-Sheikh Univ. A. Plant production, 42(4): 494-505.

Gamal, A.M. and Ragab, M.A. (2003). Effect of organic manure source and its rate on growth, nutritional status of the trees and productivity of "Balady" mandarin trees. Assiut J. of Agri. Sci., 34(6): 253-264.

Hegazi, E.S., El-Sonbaty, M.R., Ahmed, D.M. \& El-Sharony, T.F. (2007). Effect of Organic and Bio-Fertilization on Vegetative Growth and Flowering of Picual Olive Trees. World J Agric. Sci., 3, 210-217. 
Higa, T., (1986). Studies on the application of effective microorganisms in nature farming. 6th IFOAM Conference, Aug. 18-21, California Univ.,USA.

Higa, T., (1991). Effective Microorganisms: A Biotechnology for Mankind. In: Parr, J.F., S.B. Hornick and C.E. Whitman (eds.)., Proc First International Conference on Kyusei Nature Farming, 814, Depart. of Agri., Washington, DC, U.S.

Helal, Sumi, (2003). "Konark-a service discovery and delivery protocol for ad-hoc networks.", In Third IEEE Conference on Wireless Communications and Networking (WCNC), volume 3, pages 2107$2113(2003)$..

Helail, B. M.; Y. N. Gobran, and M. H. Mostafa (2003). Study on the effect of organic manure application and bio-fertilizers on. Fruiting and Fruit quality of Washington navel orange trees. Egypt. J. Appl. Sci., 18 (141): 297-320.

Kundu, S.; P. Datta; J. Mishra; K. Rashmi; and B. Ghosh (2011). Influence of Biofertilizer and Inorganic Fertilizer in Pruned Mango Orchard cv. Amrapali. of Crop and Weed, 7: 100-103.

Mohamed, Shaimaa, A. and O. N. Massoud (2017). Impact of Inoculation with Mycorrhiza and Azotobacter under Different $\mathrm{N}$ and $\mathrm{P}$ Rates on Growth, Nutrient status, Yield and Some Soil Characteristics of Washington Navel Orange Trees. Middle East J. Agric. Res., 6 (3): 617-638.

Ortas, I., and O. Ustuner. (2014)."Determination of different growth media and various mycorrhizae species on citrus growth and nutrient uptake." Scientia Hort., 166: 84-90.

Rabeh M. R. M., A. E. Hassan, F. S. E. Kassem and S. A. Nassar (2012). Growth, fruit quality and yield of mango trees as affected by some bio and mineral nitrogen fertilizers. Thesis (M.S.). Hort. Dept., Fac. Agric., Minufiya Uni., Egypt.

Rokba, A. M., El LT Mahmoudi, and El E. Menshawi. (1975). "Effect of organic and inorganic fertilizers on annual orange trees.". Agric. Res. Rev., 53.3: 7-14.

Steel, R. G. and Torrie, J. H. (1980). Principals and Procedures Of Statistics. Mcgrow-Hill publishing company. pp 1-625. NY, USA. 
Shabana, H. R., and N. S. Antoun. (1980). "The determination of leaf area in date palm." Beitrage zur Tropischen Landwirtschaft und Veterinarmedizin, 18(4): 345-349.

Tung, P. G. A.; Yusoff, M. K.; Majid, N. M.; Joo, G.K. and G. H. Huang (2009). Effect of $\mathrm{N}$ and $\mathrm{K}$ fertilizers on nutrient leaching and groundwater quality under mature oil palm in Sabah during the monsoon period. American Journal of Applied Sciences, 6 (10): 1788-1799

Wassel, A.H.; F.F. Ahmed; MA. Ragab and M.M. Ragab (2007). Response of Balady mandarin trees to drip irrigation and nitrogen fertigation. I. Effect of nitrogen fertigation and drip irrigation on the vegetative growth and the yield of Balady mandarin trees (Citrus reticulate). African Crop Sci. Conference Proceeding, 8: 503-511.

Wettstein D. (1957). Chlorophyll lethal under faktoren der sumbikroskopishe form wechlsel der plastiden. Exp. Cell. Res., 12: 427-433. 


\section{تأثير التسميد المعدني والعضوي والحيوي علي نمو نخيل البلح الزغلول}

أشرف السيد أحمد علي - أسامه أحمد ابراهيم زقزوق

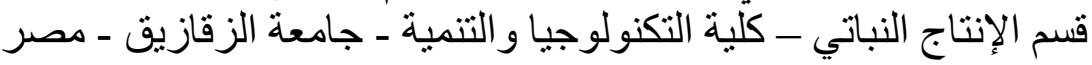

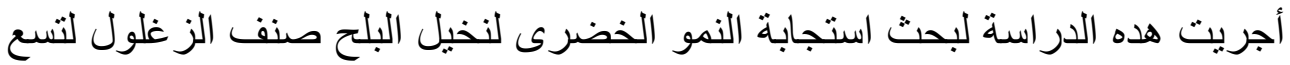

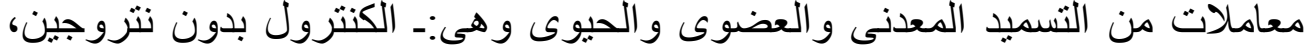

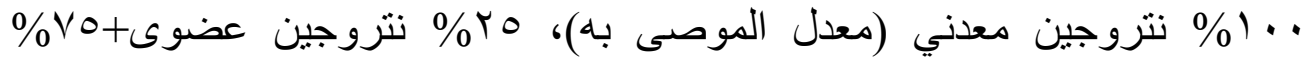

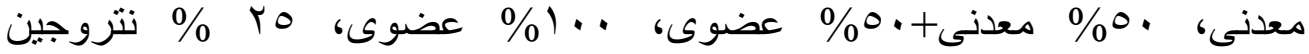

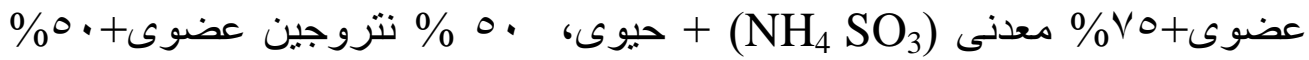

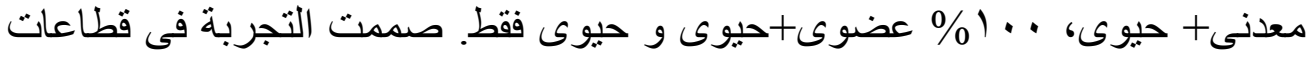
كاملة العشوائية فى ثلاث مكررات تحت ظروف بروف قرية العدلية ، بلبيس، محافظة

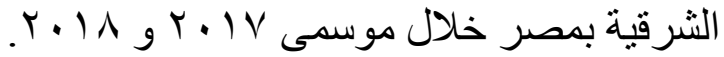

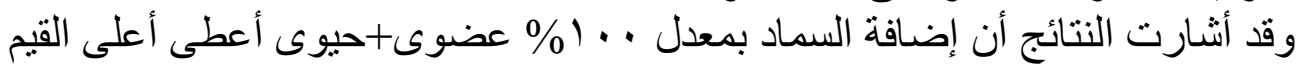

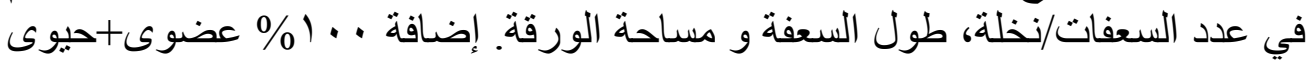

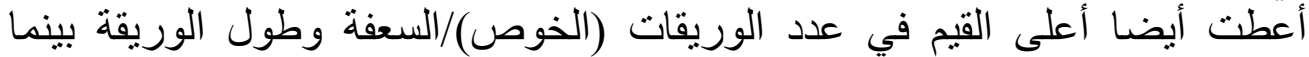

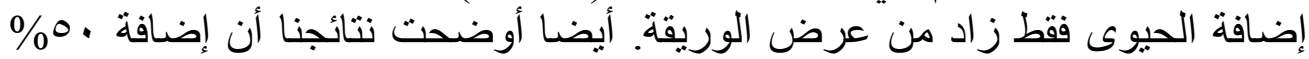

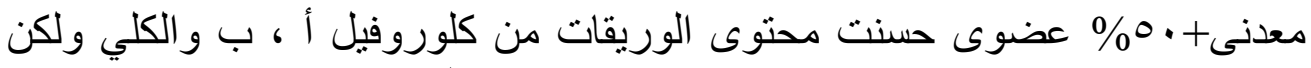

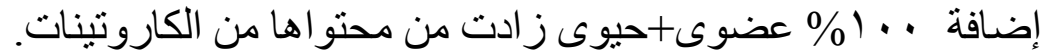

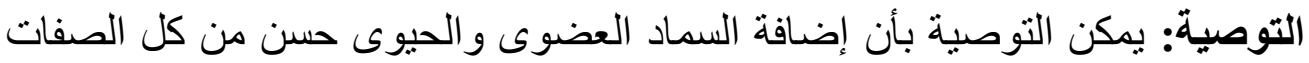

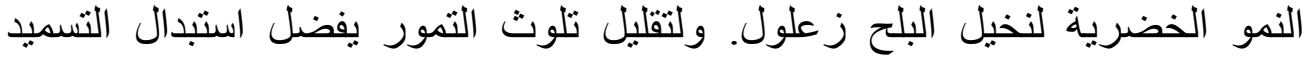

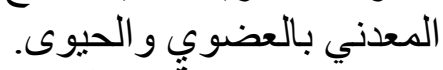
الكلمات المفتاحية: نخيل البلح ـ النمو الخضرى ـ التسميد المعدني ـ العضوى ـ الحيوي 